\title{
Trait Phenotyping and Genic/Random SSR Markers Characterization for Breeding Early Maturing Wheat's for Western-Himalayas
}

\section{Safoora Shafi}

Sher-E-Kashmir University of Agricultural Sciences and Technology Kashmir

\section{Mohd Tahir}

Sher-E-Kashmir University of Agricultural Sciences and Technology Kashmir

Mohd Anwar Khan

Sher-E-Kashmir University of Agricultural Sciences and Technology Kashmir

\section{Mohd Ashraf Bhat}

Sher-E-Kashmir University of Agricultural Sciences and Technology Kashmir

\section{Uttam Kumar}

Borlaug Institute of South Asia

\section{Sanjay Kumar}

SKUAST Kashmir: Sher-E-Kashmir University of Agricultural Sciences and Technology Kashmir

\section{Reyazul Rouf Mir ( $\square$ imrouf2006@gmail.com )}

SKAUST-Kashmir https://orcid.org/0000-0002-3196-211X

\section{Research Article}

Keywords: Bread Wheat, Early Maturity, SSRs, Allelic Diversity, Bi-parental Mapping Populations

Posted Date: March 1st, 2021

DOI: https://doi.org/10.21203/rs.3.rs-217390/v1

License: (a) (1) This work is licensed under a Creative Commons Attribution 4.0 International License. Read Full License 


\section{Abstract}

The study involves evaluation of 96 wheat genotypes for early maturity and related traits and molecular characterization of trait specific candidate genotypes using 26 (20 random and 6 genic) SSR markers. Trait characterization revealed significant variation for early maturity and related traits. The analysis of genotypic data of 26 markers led to the detection of 166 alleles ranging from 2 to 8 alleles with an average of 3.8 alleles per locus. Separate analysis of genotypic data of 20 random and 06 trait specefic markers led to the identification of 118 and 51 alleles, respectively. Sub-population-wise allelic diversity in early and late maturing populations could detect a total of 167 and 144 alleles, respectively. Higher gene diversity was detected in early maturing sub-population (0.135) when compared to late maturing sub-population (0.071). Single marker analysis (SMA) revealed significant association of 05 random and 02 trait specific markers already reported for early maturity. Therefore, two trait specific markers (Xwmc1 and Xgwm271) have been validated during the present study and contributed $21.36 \%$ and $10.94 \%$ phenotypic variation for early maturity, respectively. In order to breed for early maturity for WesternHimalayas, $F_{2}$ segregating populations were also developed by making crosses among spring $\times$ spring and spring $\times$ winter wheat genotypes and several important recombinants/ segregants for early maturity and related traits were identified. Overall, the findings of the present study will prove useful in future wheat improvement programs leading to development of early maturing wheat varieties.

\section{Introduction}

Wheat (Triticum aestivum L.) is an important cereal crop grown under diverse climatic conditions in different parts of the world. In India wheat is being cultivated in different states as an important rabi crop. Under intensive agriculture where we compete for getting more food from less area, the timely vacation of the fields are important to have more number of crops per unit area per year. The genetic improvement of early maturity trait in wheat is thus considered as an important objective of wheat breeding programs of India in general and north-western Himalayas in particular. Earliness in maturity is also considered as important factor for timely crop harvest and thus vacating field for timely rice transplantation. Breeding early maturing wheat cultivars is also expected to provide protection from biotic and abiotic stresses (Joshi et al. 2007). Various physiological mechanisms like earliness, cooler canopies, stay-green, high transpiration rate, and reduced photosynthetic rates are employed by the plants to adapt to extreme temperature stress. Under late incidence or post heading of high temperature stress, earliness provides an escape mechanism (Joshi et al. 2007) and it has been considered as a single effective trait that defines adaptation under such conditions (Tewolde et al. 2006).

Therefore, breeding for early-maturing cultivars and inheritance of early maturity and its attributes, along with the high yielding trait serves as base material for wheat breeders to develop a short duration cultivar in wheat. Wheat flowering/maturity is a complex quantitative trait controlled by set of vernalization (Vrn), photoperiod (Ppd) sensitive loci and earliness per se genes (eps) (Kato and Yamagata 1988; Zikhali and Griffiths 2015). Combinations of these genes contribute to differences in flowering and maturity time in wheat, taking into account environmental conditions (van Beem et al. 2005; Kamran et al. 2013; Gomez et al. 2014; Guedira et al. 2014; Sukumaran et al. 2016). It is of utmost importance to characterize the wheat for early maturity and related traits as there lies spatiotemporal differentiation for these traits in wheat. Various studies have shown that earliness is greatly influenced by the local climatic conditions and each genetic factor is controlled by multiple homoalleles (Goldringer et al. 2006). Potential of high-yielding and early maturing wheat lines have also been evaluated in different environmental conditions (Mondal et al. 2016). Further, genetic studies have been carried out in wheat to understand the mechanism of heading time to photoperiod responses both under normal as well as controlled conditions (Sourdille 
et al. 2000). To elucidate more about earliness in wheat, various morphological as well as molecular characterizations have been carried out earlier (Sourdille et al. 2000; Le Gouis et al. 2012; Mondal et al. 2016; Sukumaran et al. 2016; Kiseleva et al. 2016). In addition to genes for flowering/photoperiod, several molecular markers have also been found associated with flowering time/early maturity per se and other related traits through a variety of approaches. QTLs for earliness and its components are widely available, but little is known of the genetic control of earliness in wheat when compared with other species where genes and biochemical pathways are well documented, such as legumes (Weller et al. 2015) or Arabidopsis (Putterill et al. 2004).

Furthermore, the use of molecular markers for the evaluation of genetic diversity is receiving much attention as they allow calculation of genetic distance based on allele frequencies and are also useful in studying the relationship of closely related lines (Huang et al. 2002). Availability of superior and diverse alleles/genes form the basis of genetic improvement of crop plants including wheat that can help in identification of new cultivars (Abouzied et al. 2013) . In addition, SSR markers are also useful for marker-assisted selection (MAS), genetic diversity, identifying quantitative trait loci, labeling of stress-tolerant genes in wheat or its wild relatives and genetic variability studies in wheat seed-borne diseases (Landjeva et al. 2007; ljaz and Khan, 2009; Ya et al. 2017; Sharma et al. 2018; Biradar et al. 2018; Nsabiyera et al. 2018). Therefore, it was found imperative that the wheat material for early maturity be characterized (morphological characterization and molecular characterization) and already reported markers be validated on the available germplasm. This study aims at testing of a set of pre-selected wheat genotypes for early maturity, attempting promising crosses to have maximum possibility of getting a useful recombinant with extra-early maturity, develop relevant mapping populations and use random and trait specific/genic (early flowering/ maturity) SSR markers for germplasm characterization and identifying marker-trait associations for early maturity.

\section{Materials And Methods}

\section{Plant material}

The plant material used during the present study comprised of 96 wheat genotypes. The 96 wheat genotypes include 48 wheat genotypes procured from CIMMYT, BISA, Ludhiana (25 early maturing), 20 released Indian bread wheat varieties (medium maturing genotypes) from IIWBR, Karnal, 36 winter wheat genotypes (late maturing) procured from PAU, Ludhiana and 13 local wheat selections genotypes. List of material used in the study has been given in ESM Table 1. The material was evaluated along with two local released wheat varieties including Shalimar wheat-1 and Shalimar wheat-2 as checks at Faculty of Agriculture (FoA), Wadura, Sopore, Kashmir, India.

\section{Trait evaluation and trait data analysis}

The wheat germplasm (96 genotypes) were evaluated for 11 important quantitative traits viz., days to flowering, days to maturity, plant height, number of tillers, spike length, number of spikelet's per spike, number of grains per spike, thousand grain weight, yield per hectare and seed morphological traits including seed length and breadth following PPV and FRA (Protection of Plant Varieties and Farmers' Right Authority) descriptor (2007). The experiment was laid out in Random Block Design (RBD) with two replications. All the recommended package and practices were followed to raise a healthy crop. Ten plants were selected randomly before heading and tagged for recording the data. Analysis of variance for all the characters for testing variation among genotypes was carried out as per the procedure suggested by Verma et al (1987). Minimum, maximum, range, mode, mean, coefficient of variation, variance, standard error and standard deviation values have also been calculated for all the 11 traits. The data on early maturity trait was utilized for the study of marker-trait associations (MTAs) through single marker 
analysis (SMA) to identify significantly trait associated markers. The analysis of trait data also led to the identification of most promising parental genotypes for the development of biparental mapping population. All the above computations were carried out using the statistical software, Strengthening Statistical Computing for NARS IASRI (Online Consortium, 2018).

\section{SSR markers}

Based on phenotypic evaluation, a set of 57 genotypes (early and late maturing genotypes) were selected for SSR marker genotyping. A set of twenty-six (26) microsatellite or SSR markers spanning over all the 21 wheat chromosomes were selected from the consensus genetic map of wheat (Somers et al. 2004). These 26 SSR markers belongs to different series of SSR markers including WMC, GWM, GDM, CFD, CFA and BARC series of SSR markers. Details of primer sequences for all these SSRs are available elsewhere (https://wheat.pw.usda.gov/GG3/). The selected markers included both genomic as well as genic SSR markers hereafter designated as Set-I and set-II SSR markers, respectively. The Set-I including random SSR markers while as Set-II includes trait specific/genic SSR markers associated with QTLs for early flowering and maturity. Set-II markers were selected from the previous published literature (Hanocq et al. 2006; Kuchel et al. 2006; Hanocq et al. 2007; Bonnin et al. 2008; Griffiths et al. 2009; Le Gouis et al. 2012; Zanke et al. 2014). The SSR once selected were synthesized on contract from Sigma Aldrich, Bangalore, India for marker genotyping work.

\section{SSR marker genotyping}

The genomic DNA from each genotype was extracted from the leaves of one month-old plants following modified CTAB method (Saghai-Maroof et al. 1984). RNase treatment and phenol: chloroform: isoamyl alcohol precipitation was carried out for purification of isolated DNA (Sambrook et al. 1989). The basic PCR amplifications were performed in a $20 \mu \mathrm{L}$ reaction mixture containing $10 \mu \mathrm{L} 2$ x Taq PCR Master Mix, $1 \mu \mathrm{L} 50-100 \mathrm{ng} \mu \mathrm{L}^{-1} \mathrm{~g}$ DNA, $1 \mu \mathrm{L}$ $10 \mathrm{p} \mathrm{mol} \mathrm{IL}{ }^{-1}$ of each primer and $7 \mu \mathrm{L}$ sterilized $\mathrm{ddH}_{2} \mathrm{O}$ (Guo et al. 2015). The PCR profile was: Initial denaturation at $94^{\circ} \mathrm{C}$ for 5 minute, followed by denaturing at $94^{\circ} \mathrm{C}$ for 1 minute, annealing at $52-60^{\circ} \mathrm{C}$ for $30 \mathrm{~s}$, and extension at $72^{\circ} \mathrm{C}$ for 30 seconds to 2 minutes, and steps $2-4$ were repeated 34 cycles with a final extension at $72^{\circ} \mathrm{C}$ for $10 \mathrm{~min}$. The amplified products were checked on $3 \%$ agarose gels and resolved on $10 \%$ polyacrylamide denaturing gels (PAGE) followed by silver staining (see Mir et al. 2012b for details). The genotyping data (marker alleles) for all SSRs was recorded manually using the stained gels.

\section{Genotypic data analysis}

The estimation of genetic indices and AMOVA were performed using GeneAIEx 6.41 (Peakall and Smouse, 2006). Both random (20) and trait specific/genic (06) SSR marker genotypic data was used to calculate genetic indices include estimation of total number of alleles $(\mathrm{Na})$, number of effective alleles, expected heterozygosity $(\mathrm{He})$ and number of private alleles confined to a single population. All these analysis helped to compare between early and late maturing wheat sub-populations. Cluster analysis was performed using the unweighted pair group method and arithmetic average to study the genetic relationships among the cultivars. These coefficients were used to construct dendrogram using the un-weighted pair group method with arithmetic average (UPGMA) using statistical software DARwin version 6 (Perrier et al. 2003) for the classification of population into sub population and the robustness of internodes was assessed by bootstrap analysis and principal coordinate analysis (PCoA) was performed on the entire germplasm set computed from SSR markers using DARwin software (Perrier and Jacquemoud-Collet 2006). The polymorphic information content (PIC) was also calculated following Botstein et al. 1980. 


\section{See formula 1 in the supplementary files.}

Where,

$P_{i j}$ and $P_{i k}$ are the frequencies of $j^{\text {th }}$ and $k^{\text {th }}$ alleles for marker $\mathrm{i}$, respectively.

\section{Marker-trait associations through Single Marker Analysis (SMA)}

Simple linear regression was determined for days to maturity trait with all the genotypic data of all SSRs. A potential relationship between the marker and trait was established by considering the significance of the regression coefficient. Adjusted $\mathrm{R}^{2}$ value is used to judge the marker-trait relationship. $\mathrm{R}^{2}$ value gives the overall percentage of phenotypic variation explained by a particular marker for early maturity.

\section{Development of bi-parental mapping populations for early maturity and yield related traits}

Based on phenotypic and genotypic trait evaluation, a set of candidate genotypes possessing extra early maturity, late maturity, high yield and disease resistance were selected. Intercrossing was performed among the selected genotypes and with winter wheat genotypes. Two $\mathrm{F}_{2}$ bi-parental mapping populations were developed by crossing contrasting parents for early maturity and yield related traits. These include Andalou (winter wheat) / WS-1614 (spring wheat), CIMMYT-4060 (spring wheat) / Aardvark (winter wheat). Parents, their $F_{1} s$ and $F_{2} s$ were evaluated under field conditions and data was recorded for morphological traits viz., days to flowering, days to maturity, plant height, number of tillers, spike length , number of spikelets per spike and yield per plant. Mean, minimum, maximum and standard deviation values were calculated from the recorded data. In order to identify the transgressive segregants among $F_{2}$ populations, individual $F_{2}$ plant was evaluated and compared with its parents.

\section{Results And Discussion}

Early maturity, high yield and related components are important targeted traits in wheat. Many wheat breeding programmes around the globe are targeted at describing new genetic variation for early maturity and yield related traits. Breeding for early maturity is considered one of the most important and challenging tasks for wheat breeders in areas experiencing long period of cold weather followed by short crop growing periods. Thus breeding for early maturing wheats in these areas assumes importance for successful rice-wheat crop rotation. Rice-wheat crop rotation is important for doubling farmer's income in north-western Himalayas where wheat is grown during winters followed by rice in summers. Vacating wheat field on time for rice cultivation in early summers is considered one of the daunting tasks for wheat breeders. Therefore, the present study was aimed at testing of a set of wheat genotypes for early maturity, attempting crosses between contrasting parents for developing segregating populations for days to maturity and identification of early maturing recombinants. Efforts have been also made to use SSR markers (both linked to early maturity and random markers) for genotyping of the available germplasm for the genetic analysis of early maturing trait in wheat.

\section{Trait data analysis}

The frequency distribution of all the 11 important quantitative traits (days to flowering, days to maturity, plant height, number of tillers, spike length, number of spikelet's per spike, number of grains per spike, thousand grain weight, yield per hectare, seed length and seed breadth) exhibited normal distribution (Fig. 1). Values of minimum, maximum, range, mode, mean, coefficient of variation, variance, standard error and standard deviation for all the 11 traits under study have been presented in the Table 1. Coefficient of variation was highest for number of tillers, seed 
set per spike, spike length and grain yield. However, thousand grain weight and plant height showed medium coefficient of variation. It indicates the presence of sufficient amount of genetic variability for all the traits. The analysis of variance (Table 2) also revealed that the treatments were highly significant for all the 11 traits and highest value for mean sum of squares was estimated for grain yield $\left(\mathrm{kg} \mathrm{ha}^{-1}\right)$ followed by seed set per spike, while as seed length and seed breadth had lowest. Days to flowering and days to maturity traits also showed significant results. Similar kind of results were also substantiated by Singh and Sharma, (2007); Atta et al. (2008); Gupta et al. (2009); Mohsin et al. (2009); Chandra et al. (2010) and Bhuri and Upadhyay, (2013). The estimation of variation is very important for any plant breeding programme and selection is effective when the magnitude of variability in the breeding population is high. Here in our study, huge amount of variation was also detected for traits under consideration including important traits of our interest (days to flowering and days to maturity). This trait variation can be utilized for different wheat breeding programmes for the development of early maturity and high yielding varieties. Further, morphological markers and trait variation are considered as important tool for germplasm characterization and thus they play a crucial role in detection and mapping of genes of economic importance.

\section{SSR marker characterization and analyses}

The molecular characterization of a set of wheat genotypes using genomic and trait specific/genic microsatellite markers and their allelic diversity is important in selecting a core set of early maturing genotypes, the selection of parents to develop relevant mapping populations and to initiate wheat breeding programs for the areas where early maturity in wheat is an important consideration. In bread wheat, genomic SSRs have been extensively used for the study of genetic diversity (van de Wouw et al. 2010). The genetic diversity detected by genomic SSRs may not represent "true genetic diversity" as most of these markers may detect polymorphism in non-coding and poorly conserved regions of the genome among species (Brown et al. 2001; Gupta et al. 2003). Therefore, SSR markers associated with trait of interest and selected from the genic regions may help to detect true genetic diversity. Keeping in view, two set of SSR markers were used in the present study. Set-I include the random SSR markers while as Set-II include SSR markers associated with QTLs for early maturity and related traits (Hanocq et al. 2006; Kuchel et al. 2006; Hanocq et al. 2007; Bonnin et al. 2008; Griffiths et al. 2009; Gouis et al. 2012; Zanke et al. 2014). The results of the SSR markers used for characterization of 57 genotypes are presented below:

\section{SSR allelic diversity: genomic vs genic SSRs}

Twenty-six SSR markers (20 random and 06 genic SSR markers) were tested on 57 wheat genotypes during the present study for their characterization. These SSRs were distributed on 15 chromosomes $(2 \mathrm{~A}, 3 \mathrm{~A}, 4 \mathrm{~A}, 5 \mathrm{~A}, 6 \mathrm{~A}, 7 \mathrm{~A}, 1 \mathrm{~B}$, $2 B, 3 B, 4 B, 1 D, 2 D, 3 D, 4 D$ and 5D chromosomes). These 26 markers led to the amplification of 53 genomic loci including 37 loci by random and 16 loci by genic SSRs. The 20 random markers tested on 57 genotypes could detect 118 alleles with an average of 3.10 alleles, while as 6 genic SSRs detected a total of 51 alleles with an average of 3.20 alleles/locus. The number of effective alleles detected was 84.09 and 51 respectively, for random and genic markers. While analyzing the data separately, the number of private and common alleles detected was also compared between the random and genic SSRs. The random SSRs detected an average of 3.2 private alleles, whereas the genic SSRs detected an average of 3.1 private alleles. Expected heterozygosity $(H e)$ per locus in case of random SSRs ranged from $0.188(X c f d 39 B)$ to $0.838(X c f d 267 B)$ with an average value of 0.506 , while as for genic SSRs it ranged from 0.233 (Xcfb3266A, Xcfb3266C) to 0.774 (Xgwm453B) with an average of 0.450 . The average value of PIC (Polymorphic Information Content) for all markers was 0.518 , ranging from 0.188 (Xcfd39B) to 0.838 (Xcfd267B) (Table 3). By analyzing the above parameters, the diversity detected by the SSRs associated with QTLs for early maturity and related traits (Set-II SSRs) was slightly lower than the diversity detected by the random SSRS 
(Set-I). Private alleles detected by the random SSRs were also slightly more than the trait specefic/genic SSRs. One possible reason may be the use of less number of trait specific SSRs. Other reason may include the selection pressure on the SSRs associated with the QTLs for early maturity and related traits. These results during the present study were expected and are in agreement with our earlier results on Indian wheats (Mir et al. 2012a) where less diversity was detected by SSR markers associated with grain weight compared to random genomic SSR markers. The random SSRs could detect a total of 295 alleles (average alleles/locus $=7.02$ ) while as trait specefic/genic SSRs for grain weight could detect 220 alleles (average number of alleles/locus $=4.59$ ) in released Indian wheat varieties (Mir et al. 2012a). The less diversity detected during the present study by us may be due to trait specific germplasm (early maturing germplasm) used during the present study where targeted breeding programs leads to reduction in genetic diversity. Other researchers have also reported less genetic diversity in different wheat collections with average number of alleles per locus ranging from 2.36 to 3.5 (Drikvand et al. 2015; Kumar et al. 2016). Drikvand et al. (2015) assessed genetic diversity of some durum and bread wheat genotypes and distinguished a total of 71 alleles. In contrast, some findings have described high level of genetic diversity as reflected by allele number per locus ranging from 4-18 alleles per locus in various wheat collections (Huang et al. 2002; Roussel et al. 2004; Maccaferri et al. 2005; Zhang et al. 2010; Chen et al. 2012). Roussel et al. 2004 evaluated genetic diversity of 559 French wheat accessions and reported 14.5 alleles per locus and a polymorphic information content (PIC) value of 0.66. Interestingly, the mean PIC value of SSR markers recorded in the present study was moderate (0.188 to 0.838 with the mean PIC value of 0.518 ). This was in agreement with earlier studies (Roussel et al. 2004; Zhang et al. 2010; Mir 2012a; Arora 2014). Furthermore, our findings have well justified the potential of primers selected for assessing genetic diversity in the set of wheat germplasm. The primer Xgwm453 with highest Shannon's Information Index was identified as most potential primer for genetic diversity studies in wheat. Such primers can be recommended and used for wheat genetic diversity studies in future. In addition, maximum He was recorded in the present study ( 0.506 for Set-I, and 0.450 for Set-II) which is in agreement with our previous study where also maximum heterozygosity was found for both the sets of markers (He 0.65 in Set-I and 0.55 in Set-II) (Mir et al. 2012a).

\section{Allelic diversity: early vs late maturing sub-populations}

The allelic diversity of early maturing genotypes when compared to late maturing genotypes led to identification of 167 alleles in early maturing genotypes with an average of 3.00 alleles/locus. The average number of alleles with frequency $>=5 \%$ was 2.73 and the number of effective alleles were 120.625 with an average of 2.16. Similarly, gene diversity (expected heterozygosity; $\mathrm{He}$ ) varied from 0.135 to 0.703 with an average of 0.461 . The lowest $H e(0.145)$ was recorded for SSR marker Xgwm383A and highest (0.830) for SSR marker Xcfd31B. Similarly, for late maturing group, the total number of alleles detected in the germplasm was 144 with an average of 2.81 alleles/locus. The average number of alleles with frequency $>=5 \%$ was 2.64 and the number of effective alleles were 112.080 with an average of 2.06. Similarly, gene diversity (expected heterozygosity; $\mathrm{He}$ ) varied from 0.071 to 0.656 with an average of 0.45. The lowest $\mathrm{He}(0.091)$ was recorded for SSR marker Xgwm383A and highest (0.756) for SSR marker Xgwm 190A. The number of alleles unique to a single population were present more in early maturing population (0.377) as compared to that of late maturing population (0.189) (Table 4). Upon measuring and comparing genetic diversity among populations, estimated number of different alleles, effective alleles, private alleles (number of alleles unique to a single population) and expected heterozygosity was more in case of early maturing population as compared to that of late maturing population (Fig 2). These results confirmed the differences between two populations on molecular basis and thus can be used as an effective tool for the study of genetic dissimilarity among the two populations and selection of parents from the two populations. These results were in agreement with those of Zhang et al. (2006), who emphasized that SSRs were an effective marker system for detecting genetic 
diversity among wheat and related species and provided useful information about the phylogenic relationships. The present study also demonstrated that the wheat genotypes could be distinguished by these SSR markers showing high level of polymorphism. This also leads to the parental characterization (using SSR markers) of genotypes involved in various cross combinations for early maturity and related traits.

Furthermore, to evaluate the extent of population differentiation, the analysis of molecular variance (AMOVA) based on 99 permutations was analyzed and the genetic variation within and between populations was quantified. The $\mathbb{\mathrm { P }}_{\mathrm{PT}}$ (analogue of FST fixation index) value for genetic variability and the percentage of polymorphism (\%) were calculated for each population, using GenALEx 6.41. Molecular analysis of variance showed that $91 \%$ of the diversity was distributed within populations and $9 \%$ among populations (Table 5). The high $\rrbracket_{\mathrm{PT}}$ value $(0.093, P=$ $0.010)$ indicates significant genetic variability. A sense of genetically significant difference was found in the early and late maturing populations. These results also correspond to those of Donini et al. (2000); Mir et al. (2012a); Manickavelu et al. (2014). AMOVA partitioned $10 \%$ of the total variation for genetic diversity as among sub-cluster and $90 \%$ as within sub-cluster in the distance-based analysis (Zhang et al. 2010). Similar studies have reported that genetic diversity losses have been observed in recent times attributable to breeding in bread wheat (Christiansen et al. 2002; Reif et al. 2005; Warburton et al. 2006; Huang et al. 2007; Hysing et al. 2008).

\section{Cluster analysis}

The un-weighted neighbor joining (UNJ) dendrogram of random markers constructed on the basis of genetic dissimilarity matrix grouped the cultivars into two groups, early and late maturity population. One largely carrying cultivars belonging to CIMMYT wheat group, and the other largely carrying those belonging to winter wheat group and some promising wheat varieties. Principal coordinate analysis also separated the 57 genotypes into two major groups, which was consistent with assignments generated by UPGMA clustering (Fig. 3). The genotypes belonging to group 1 were mainly distributed in the lower left portion of the resulting plot, with group 2 distributed in the upper right and lower right, indicating higher diversity among the two groups. These results were later on confirmed by the single marker analysis results which led to the identification of some new marker-trait associations with early maturity (see section single marker analysis). Therefore, these markers associated with early maturity among random markers may be responsible for trait specific grouping of genotypes using random markers.

UPGMA cluster analysis using non-random markers i.e., trait specific genic markers also led to clear cut separation of genotypes based on their trait values (days to maturity). The analysis divided the 57 genotypes into three major groups thus depicting high resolving power of specific markers. Each group is divided into further two sub groups carrying early and late maturing genotypes in different sub groups as presented in the figure 4. This grouping pattern also supported the conclusion that the groups of cultivars differed genetically and demonstrating the superiority of trait specific markers in cluster analysis. Principal coordinate analysis also separated the 57 genotypes into different groups, which was consistent with assignments generated by UPGMA clustering (Fig 4). In our earlier study also, we have demonstrated the clustering of 263 Indian wheat varieties into two groups: pre-green revolution period varieties and post-green revolution period varieties (Mir et al. 2012a).

\section{Single marker analysis (SMA)}

Incorporation of genomics and marker assisted selection (MAS) into breeding programmes often results in increase in the genetic gains by nearly two- fold compared to standard phenotypic selection (Battenfield et al. 2016; Crain et al., 2018). Marker-assisted selection (MAS) or molecular breeding offers an opportunity to accelerate the traditional breeding programs. Single marker analysis was conducted for days to maturity with Set-I (random SSRS) and Set-II 
(trait specific/genic) SSRs. The aim was to identify new marker trait association and validate already known to be associated with early maturity (trait specific markers). Interestingly markers were found associated with early maturity from both sets of SSR markers used during the present study. The results of Single Marker Analysis (SMA) using random markers and trait specific markers are presented in Table 6. Days to maturity showed significant association with 05 out of 20 random markers. The phenotypic variation explained (PVE\%) by these random markers varied from $7.61 \%$ to $18.57 \%$ (Table 6a). Among these 05 associated SSR markers, the marker Xgwm148 explained $18.57 \%$ phenotypic variation for early maturity followed by the marker Xcfd31 explaining $13.34 \%$ phenotypic variation. Interestingly, markers $X c f d 31$ and $X g w m 148$ have also been previously reported to be associated with QTL for grain Zn (QZn.pau-7A) $\left(\mathrm{R}^{2}=18.8 \%\right)$ and slow rusting resistance genes (QYrlu.cau-2BS1) ( $\mathrm{R}^{2}$ $=36.6 \%$ ), respectively (Guo et al. 2008; Tiwari et al. 2009; Hua et al. 2009). Thus, these marker trait associations can prove useful in wheat breeding programs after future validation. Similarly, while testing MTAs of trait specific markers reported for early maturity, 02 markers out of 06 trait specific SSR markers were again found associated for early maturity and therefore validated (Table 6b). These validated markers Xwmc1 and Xgwm271 explained $21.36 \%$ and $10.94 \%$ phenotypic variation for early maturity trait, respectively. Therefore, during the present study markers like Xwmc1 and Xgwm271 with highest $\mathrm{R}^{2}$ values have been validated for early maturity. This study concluded that these SSR markers could introduce a great benefit for breeding programs to select early genotypes without waiting field evaluation and could be used in marker assisted selection for earliness trait. These results also support the idea that SSR markers can provide fast detection of genes of interest. Trait-linked DNA markers have been identified for numerous traits in wheat, including disease resistance and grain quality (Helguera et al. 2003; Williams et al. 2002; Daetwyler et al. 2014; Qureshi et al. 2018; Li et al. 2018; Camargo Rodriguez et al. 2018; Kumar et al. 2018). All these identified markers in various studies are being successfully utilized for wheat breeding programmes throughout the world.

\section{Trait analysis of bi-parental $\left(F_{2}\right)$ mapping population for early maturity and yield related traits}

Highly significant differences were found among the four parental genotypes for days to flowering, days to maturity, plant height, effective tillers per plant, spike length, spikelets per spike and grain weight per plant. For days to maturity, one winter $\times$ spring and one spring $\times$ winter wheat crosses Andalou (winter wheat) / WS-1614 (spring wheat) and CIMMYT-4060 (spring wheat) / Aardvark (winter wheat) had significant differences among parents of about 30 and 50 days, respectively. Average days to maturity recorded for $F_{1} s$ was 240 for both the crosses. Total $150 \mathrm{~F}_{2}$ plants were screened from both the crosses. In case of $F_{2} s$, days to maturity ranged from 225 to 260 days with an average of 239.6 days and 218 to 276 days with an average of 249.7 days, respectively. Data obtained for other early maturity and related traits also showed significant differences as has been presented in Table 7 and Table 8. Few transgressive segregants have been identified with yield ranging from 30-33 gm per plant and having early maturity ranging from 225-228 days. Spike length which is also an important yield contributing trait ranged from $13-14 \mathrm{~cm}$ for the identified plants. The $F_{2}$ plants thus identified can be used for further breeding programmes in wheat. The main aim of our study was to identify several transgressive segregants that resulted from both the crosses for traits like early flowering, early maturity and yield. The existence of genetic variation for early maturity, yield and its components in both of the crosses indicates that these crosses have the potential that can be exploited through selection from the recombinant inbred lines in advanced generations.

In wheat different types of multi-parental populations have been developed in order to obtain greater precision in fine mapping with little or no genetic structure. One approach is to combine different biparental populations, for example, diallels or factorial crosses (Rebai and Goffinet, 1993) or crosses with a common reference line (nested association mapping, NAM (Yu et al. 2008). The biparental maping populations developed in 
our study can be used for such breeding programs in future. Other method involves complete allele reshuffling by operating circular or pyramidal crosses between 4, 8, or 16 parents that is called as Multiparent Advanced Generation Inter-Cross (MAGIC) populations (Cavanagh et al. 2008; Huang et al. 2012). In self-pollinating cereals such as wheat, selection of parents as well as genetic distance between them is important for breeding programs. This will also lead to obtain transgressive segregants (Joshi et al. 2004; Khodadadi et al. 2011). For discovering genetic diversity it is also important to know the genetic structure of a population (Hao et al. 2011; Zhang et al. 2011; Abebe and Le'on 2012). Therefore for these reasons selection of parents is very crucial step in any breeding programme. Present investigation also suggests that selection in $F_{2}$ population will be effective in selecting superior plants for early maturity, grain yield and disease resistance. Large number of $F_{2}$ segregants have been identified which require less number of days to maturity as compared to that of parents as well as two check varieties (SW1 and SW2) from spring $x$ winter crosses (Andalou x WS-1614), (CIMMYT-4060 x Aardvark). Previous findings support the present results. To check improvement for grain filling period in $F_{2}$-derived $F_{3}$, Sharma, (1994) considered interand intra-population variability of plant type and maturity in six $F_{2}$ populations of spring wheat. Further, $F_{2}$ populations from 12 crosses and their parents were evaluated for grain yield in tef (Tefera et al. 2008). Fabrizius et al. (1998) studied the effect of parental diversity in spring wheat cultivars on diversity and heterosis in $137 F_{2}$ bulks developed from crosses of 91 cultivars. Within and across environments, $F_{2}$ bulks yielded more, headed earlier, and grew taller than their parents. $F_{2}$ crosses with parents unrelated by pedigree or morphology showed greater heterosis than crosses with related parents. In another study by Talbert et al. (2001), significant differences were observed among the early generations of 12 crosses of spring wheat and their interaction with environment for several traits that included grain yield, heading date, grain fill duration and test weight.

\section{Declarations}

\section{Acknowledgement}

The authors are thankful to Indian Institute of Wheat and Barley Research (IIWBR), Karnal, Haryana India, CIMMYTs Borlaug Institute for South Asia (BISA), Ludhiana, India for providing germplasm to carry out this research. The authors are highly thankful to Dean Faculty of Agriculture, SKUAST-K, and Head Division of Genetics and Plant Breeding, Faculty of Agriculture, SKUAST-K, for providing different facilities during the study.

Funding: This study was not funded by any funding agency.

Conflict of interest: The authors declare that they have no conflict of interest.

Ethical approval: This article does not contain any studies with human participants or animals performed by any of the authors.

Consent to participate: Not applicable

Consent for publication: Not applicable

Availability of data and material (data transparency): The authors confirm that the data supporting the findings of this study are available within the article [and/or] its supplementary materials

Code availability: Not applicable

Page $10 / 24$ 


\section{References}

Abbasabad EZ, Mohammadi SA, Moghaddam M, Kamali MRJ (2017) Analysis of genetic diversity population structure and linkage disequilibrium in Iranian wheat landraces using SSR markers. Plant Genet. Resour. 15: 327334.

Abbasov M, Akparov Z, Gross T, Babayeva S, Izzatullayeva V, Hajiyev E, Chao S (2018) Genetic relationship of diploid wheat (Triticum sp.) species assessed by SSR markers. Genet. Resour. Crop Evol. 65: 1441-1453.

Abebe TD, Le'on J (2012) Spatial and temporal genetic analyses of Ethiopian barley (Hordeum vulgare L.) landraces reveal the absence of a distinct population structure. Genet. Resour. Crop Evol. 60: 1547-1558.

Abouzied HM, Eldemery SMM and Abdellatif KF (2013) SSR-based genetic diversity assessement in tetraploid and hexaploid wheat populations. British Biotechnol J. 3: 390- 404.

Aliyev RT, Abbasov MA, Mammadov AC (2007) Genetic identification of diploid and tetraploid wheat species with RAPD markers. Turk. J. Biol. 31: 173-180.

Atta BM, Yousaf A, Javed A, Monne Veux P, Zahid L (2008) Genetic variability association and diversity studies in wheat (Triticum aestivum L) germplasm. Pak. J. Bot. 40: 2087-2097.

Battenfield SD, Guzman C, Gaynor RC, Singh RP, Peña RJ, Dreisigacke S, Fritz AK, Poland JA (2016) Genomic selection for processing and end-use quality traits in the CIMMYT spring bread wheat breeding program. Plant Genome 9: 1-12.

Bhuri S, and Upadhyay PK (2013) Genetic variability, correlation and path analysis in wheat (Triticum aestivum L.). Inter. J. Plant Sci. 2:230-235.

Biradar SS, Lohithaswa HC, Desai SA, Savitha BS, Naik R (2018) Identification of SSR marker linked to leaf rust resistant gene Lr24 and marker assisted transfer of leaf rust resistance genes into bread wheat. J. Agr. Sci. Tech. 18: 545-552.

Bonnin I, Rousset M, Madur D, Sourdille P, Dupuits C, Brunel D, Goldringer I (2008) FT genome A and D polymorphisms are associated with the variation of earliness components in hexaploid wheat. Theor. Appl. Genet. 116: 383-394.

Botstein D, White RL, Skolnick M, Davis RW (1980) Construction of a genetic linkage map in man using restriction fragment length polymorphisms. Am. J. Hum. Genet. 32: 314.

Brown GR, Kadel EE III, Bassoni DL, Kiehne KL, Temesgen B, van Buijtenen JP, Sewell MM, Marshall KA, Neale DB (2001) Anchor reference loci in loblolly pine (Pinus taeda L.) for integrating pine genomics. Genetics 159: 799-809.

Camargo Rodriguez AV, Mackay I, Mott R, Han J, Doonan J, Askew K, Bentley A (2018) Functional mapping of quantitative trait loci (QTLs) associated with plant performance in a wheat magic mapping population. Front. Plant Sci. 9: 887.

Cavanagh C, Morell M, Mackay I, Powell W (2008) From mutations to MAGIC: resources for gene discovery validation and delivery in crop plants. Curr. Opin. Plant. Biol. 11: 215-221. 
Chandra D, Raghav S, Saroj R, Singh DK, Sharma R, Sharma SK (2010) Genetic Variability for quantitative traits in wheat (Triticum aestivum L.). Plant Arch. 10: 871-874.

Chen X, Min D, Yasir TA, and Hu YG (2012) Genetic diversity population structure and linkage disequilibrium in elite Chinese winter wheat investigated with SSR markers. PLoS One 7: e44510.

Christiansen MJ, Andersen SB, Ortiz R (2002) Diversity changes in an intensively bread wheat germplasm during the $20^{\text {th }}$ century. Mol. Breed. 9: 1-11.

Crain J, Mondal S, Rutkoski J, Singh RP, Poland J (2018). Combining high-throughput phenotyping and genomic information to increase prediction and selection accuracy in wheat breeding. The Plant Genome 11: 1-14.

Daetwyler HD, Bansal UK, Bariana HS, Hayden MJ, Hayes BJ (2014) Genomic prediction for rust resistance in diverse wheat landraces. Theor. Appl. Genet. 127: 1795-1803.

Donini P, Law JR, Koebner RMD, Reeves JC, Cooke RJ (2000) Temporal trends in the diversity of UK wheat. Theor. Appl. Genet. 100: 912-917.

Drikvand MR, Najafian G, Elham, Salahvarzi A (2015) Investigation of genetic diversity of some durum and bread wheat genotypes using SSR markers. J. Biodivers. Environ. Sci. 6: 24-32.

Fabrizius MA, Busch RH, Khan K, Huckle L (1998) Genetic diversity and heterosis of spring wheat crosses. Crop Sci. 38: 1108-1112.

Goldringer I, Prouin C, Rousset M, Galic N, Bonnin I (2006) Rapid differentiation of experimental populations of wheat for heading time in response to local climatic conditions. Ann. Bot. 98: 805-817.

Gomez D, Vanzetti L, Helguera M, Lombardo L, Fraschina J, Miralles DJ (2014) Effect of Vrn-1 Ppd-1 genes and earliness per se on heading time in Argentinean bread wheat cultivars. Field Crops Res. 158: 73-81.

Griffiths S, Simmonds J, Leverington M, Wang Y, Fish L, Sayers L, Faure S (2009) Meta-QTL analysis of the genetic control of ear emergence in elite European winter wheat germplasm. Theor. Appl. Genet. 119: 383-395.

Guedira M, Maloney P, Xiong M, Petersen S, Murphy JP, Marshall D, Johnson J, Harrison S, Brown-Guedira G (2014) Vernalization duration requirement in soft winter wheat is associated with variation at the VRN-B1 locus. Crop Sci. 54: 1960-1971.

Guo Q, Zhang ZJ, Xu YB, Li GH, Feng J, Zhou Y (2008) Quantitative trait loci for high-temperature adult-plant and slow-rusting resistance to Puccinia striiformis f. sp. tritici in wheat cultivars. Phytopathology. 98(7): 803-809.

Guo XR, Wang YY, Meng LZ, Liu HW, Yang L, Zhou Y, Zhang HJ (2015). Distribution of the Vrn-D1b allele associated with facultative growth habit in Chinese wheat accessions. Euphytica 206: 1-10.

Gupta PK, Rustgi S, Sharma S, Singh R, Kumar N, Balyan HS (2003) Transferable EST-SSR markers for the study of polymorphism and genetic diversity in bread wheat. Mol. Genet. Genom. 270: 315-323.

Gupta S, Mukherjee S, Bhowmik N (2009) Evaluation of variability parameters in short duration wheat (Triticum aestivum $\mathrm{L}$ ) genotypes under late sown condition in Tarai region of West Bengal. Advances in Plant Sciences 22: 353-356.

Page $12 / 24$ 
Hanocq E, Laperche A, Jamino O, Laine AL, Le Gouis J (2007) Most significant genome regions involved in the control of earliness traits in bread wheat as revealed by QTL meta-analysis. Theor. Appl. Genet. 114: 569-584.

Hanocq E, Laperche A, Jaminon O, Lainé AL, Le Gouis J (2006) Most significant genome regions involved in the control of earliness traits in bread wheat as revealed by QTL meta-analysis. Theor. Appl. Genet. 114: 569-584.

Hao C, Wang L, Ge H, Dong Y, Zhang X (2011) Genetic diversity and linkage disequilibrium in Chinese bread wheat (Triticum aestivum $\mathrm{L}$ ) revealed by SSR markers. PLoS One 6: e17279.

Helguera M, Khan IA, Kolmer J, Lijavetzky D, Zhong-Qi L, Dubcovsky J (2003) PCR assays for the Lr37-Yr17-Sr38 cluster of rust resistance genes and their use to develop isogenic hard red spring wheat lines. Crop Sci. 43: 18391847.

Hua W, Liu Z, Zhu J, Xie C, Yang T, Zhou Y, Liu Z (2009) Identification and genetic mapping of pm42, a new recessive wheat powdery mildew resistance gene derived from wild emmer (Triticum turgidum var. dicoccoides). Theor. Appl. Genet. 119(2): 223-230.

Huang BE, George AW, Forrest KL, Kilian A, Hayden MJ (2012) A multiparent advanced generation inter-cross population for genetic analysis in wheat. Plant Biotechnol. J. 10: 826-839.

Huang M, Mheni N, Brown-Guedira G, McKendry A, Griffey C, Van Sanford D, Sneller C (2018) Genetic analysis of heading date in winter and spring wheat. Euphytica 214: 128.

Huang XQ, Börner A, Röder MS, Ganal MW (2002) Assessing genetic diversity of wheat (Triticum aestivum L.) germplasm using microsatellite markers. Theor. Appl. Genet. 105: 699-707.

Huang XQ, Wolf M, Ganal MW, Orford S, Koebner RMD, Röder MS (2007) Did modern plant breeding lead to genetic erosion in European winter wheat varieties? Crop Sci. 47: 343-349.

Hysing SC, Säll T, Nybom H, Liljeroth E, Merker A, Orford S, Koebner RM (2008) Temporal diversity changes among 198 Nordic bread wheat landraces and cultivars detected by retro-transposon-based S-SAP analysis. Plant Genet. Resour. 6: 113-125.

ljaz S and Khan I (2009) Molecular characterization of wheat germplasm using microsatellite markers. Genet. Mol. Res. 8: 809-815.

Joshi AK, Mishra B, Chatrath R, Ferrara GO, Singh RP (2007) Wheat improvement in India: present status emerging challenges and future prospects. Euphytica 157: 431-446

Joshi BK, Mudwari A, Bhatta MR, Ferrara GO (2004) Genetic diversity in Nepalese wheat cultivars based on agromorphological traits and coefficients of parentage. J. Nep. Agric. Res. 5: 7-17.

Kamran A, Iqbal M, Navabi A, Randhawa H, Pozniak C, Spaner D (2013) Earliness per se QTLs and their interaction with the photoperiod insensitive allele Ppd-D1a in the Cutler 3 AC Barrie spring wheat population. Theor. Appl. Genet. 126: 1965-1976.

Kato K, Yamagata H (1988) Method for evaluation of chilling requirement and narrow-sense earliness of wheat cultivars. J.P.N. J. Breed. 38: 172-186. 
Khodadadi M, Fotokian MH, Miransari M (2011) Genetic diversity of wheat (Triticum aestivum L.) genotypes based on cluster and principle component analyses for breeding strategies. Aust. J. Crop. Sci. 5: 17-24.

Kiseleva AA, Shcherban AB, Leonova IN, Frenkel Z, Salina EA (2016) Identification of new heading date determinants in wheat 5B chromosome. BMC Plant Biol. 16:8.

Kuchel H, Hollamby G, Langridge P, Williams K, Je Veries SP (2006) Identification of genetic loci associated with earemergence in bread wheat. Theor. Appl. Genet. 113:1103-1112

Kumar A, Jain S, Elias EM, Ibrahim M, Sharma LK (2018) An overview of QTL identification and marker-assisted selection for grain protein content in wheat. In: Eco-friendly Agro-biological Techniques for Enhancing Crop Productivity pp 245-274.

Kumar S, Kumar V, Kumari P, Kirti Singh AK, Singh R (2016) DNA fingerprinting and genetic diversity studies in wheat genotypes using SSR markers. J. Environ. Biol. 37:319-326.

Landjeva S, Korzun V, Börner A (2007) Molecular markers: Actual and potential contributions to wheat genome characterization and breeding. Euphytica 156:271-296.

Le Gouis J, Bordes J, Ravel C, Heumez E, Faure S, Praud S, Galic N, Remoue C, Balfourier F, Allard V, Rousset M (2012). Genome-wide association analysis to identify chromosomal regions determining components of earliness in wheat. Theor. Appl. Genet. 124:597-611.

Li F, Wen W, He Z, Liu J, Jin H, Cao S, Xia X (2018) Genome-wide linkage mapping of yield-related traits in three Chinese bread wheat populations using high-density SNP markers. Theor. Appl. Genet. 131:1903-1924.

Liu ZH, Anderson JA, Hu J, Friesen TL, Rasmussen JB, Faris JD (2005) A wheat intervarietal genetic linkage map based on microsatellite and target region amplified polymorphism markers and its utility for detecting quantitative trait loci. Theor. Appl. Genet. 111:782-794.

Maccaferri M, Sanguineti MC, Noli E, Tuberosa R (2005) Population structure and long-range linkage disequilibrium in a durum wheat elite collection. Mol. Breed. 15:271-289.

Manickavelu A, Jighly A, Ban T (2014) Molecular evaluation of orphan Afghan common wheat (Triticum aestivum L) landraces collected by Dr Kihara using single nucleotide polymorphic markers. BMC Plant Biol. 14:320.

Mir RR, Kumar J, Balyan HS, Gupta PK (2012a) a study of genetic diversity among Indian bread wheat (Triticum aestivum L.) cultivars released during last 100 years. Genet. Resour. Crop. Evol. 59:717-726.

Mir RR, Kumar N, Jaiswal V, Girdharwal N, Prasad M, Balyan HS, Gupta PK (2012b) Genetic dissection of grain weight in bread wheat through quantitative trait locus interval and association mapping. Mol Breed. 29:963-972.

Mohsin T, Khan N, Naqvi FN (2009) Heritability phenotypic correlation and path coefficient studies for some agronomic characters in synthetic elite lines of wheat. J. Food. Agric. and Environ. 7:278-282.

Mondal S, Singh RP, Masonb ER, Espinoa JH, Autriquea E, Joshi AK (2016) Grain yield adaptation and progress in breeding for early-maturing and heat-tolerant wheat lines in South Asia. Field Crops Res. 192:78-85. 
Narzary D, Mahar KS, Rana TS, Ranade SA (2009) Analysis of genetic diversity among wild pomegranate in Western Himalayas using PCR methods. Sci. Hortic. 121:237-242.

Nsabiyera V, Bariana HS, Qureshi N, Wong D, Hayden MJ, Bansal UK (2018) Characterization and mapping of adult plant stripe rust resistance in wheat accession Aus27284. Theor. App. Genet. 131:1459-1467.

Ozkan H, Brandolini A, Schafer-Pregl R, Salamini F (2002) AFLP analysis of a collection of tetraploid wheats indicates the origin of emmer and hard wheat domestication in South-East Turkey. Mol. Biol. Evol. 19:1797-1801.

Peakall ROD, Smouse PE (2006) GENALex 6: Genetic analysis in Excel Population genetic software for teaching and research. Mol. Ecol. Notes 6:288-295.

Perrier X, Flori A, Bonnot F (2003) Data analysis methods In: Genetic diversity of cultivated tropical plants Enfield: Science Publishers pp 43-76.

Perrier X, Jacquemoud-Collet JP (2006) DARwin software v 60010 http://darwinciradfr/.

Poehlman JM, Sleper DA (1995) Breeding field crops lowa State University Press Ames lowa United States of America 151:345-349.

Putterill J, Laurie R, Macknight R (2004) It's time to flower: the genetic control of flowering time. Bioessays 26:363373.

Qureshi N, Bariana HS, Zhang P, Mclntosh R, Bansal UK, Wong D, Shankar M (2018) Genetic relationship of stripe rust resistance genes Yr34 and Yr48 in wheat and identification of linked KASP markers. Plant Dis. 102:413-420.

Rebai A, Goffinet B (1993) Power of tests for QTL detection using replicated progenies derived from a diallel cross. Theor. Appl. Genet. 86:1014-1022.

Reif JC, Zhang P, Dreisigacher S, Warburton ML, Ginkel MV, Hoisington D, Bohn M, Melchinger AE (2005) Wheat genetic diversity trends during domestication and breeding. Theor. Appl. Genet. 110: 859-864.

Roussel V, Koenig J, Beckert M, Balfourier F (2004) Molecular diversity in French bread wheat accessions related to temporal trends and breeding programmes. Theor. Appl. Genet. 108: 920-930.

Rousset M, Bonnin I, Remoué C, Falque M, Rhoné B, Veyrieras JB, Santoni S (2011) Deciphering the genetics of flowering time by an association study on candidate genes in bread wheat (Triticum aestivum L). Theor. Appl. Genet. 123: 907.

Saghai-Maroof MA, Soliman KM, Jorgensen RA, Allard RW (1984) Ribosomal DNA spacer length polymorphism in barley: Mendelian inheritance chromosomal location and population dynamic. PNAS USA 81:8014-8019.

Sajjad M, Khan SH, Shahzad M (2018) Patterns of allelic diversity in spring wheat populations by SSRMarkers. Cytol. Genet. 52(2):155-160.

Sambrook J, Fritsch EF, Maniatis T (1989) Molecular cloning: a laboratory manual (Ed 2) Cold spring harbor laboratory press.

Sharma RC (1994) Early generation selection for grain filling period in wheat. Crop Sci. 34:945-948

Page $15 / 24$ 
Sharma V, Kumari S, Kumar A (2018) Phenotyping of wheat cultivar (Triticum aestivum L) using DUS characters to work out genetic variability. Int. J. Commun. Syst. 6:3266-3270.

Singh T, Sharma RK (2007) Genetic variability character association and path analysis of yield and its component characters in durum wheat. Progressive Agriculture 7:15-18.

Somers DJ, Isaac P, Edwards K (2004) A high-density microsatellite consensus map for bread wheat (Triticum aestivum L.). Theor. Appl. Genet. 109:1105-1114.

Sourdille P, Snape JW, Cadalen T, Charmet G, Nakata N, Bernard S, Bernard M (2000) Detection of QTLs for heading time and photoperiod response in wheat using a doubled-haploid population. Genome 43:487-494.

Sukumaran S, Lopes MS, Dreisigacker S, Dixon LE, Zikhali M, Griffiths S, Zheng B, Chapman S, Reynolds MP (2016) Identification of earliness per se flowering time locus in spring wheat through a genome-wide association study. Crop Sci. 56:2962-2972.

Talbert LE, Lanning SP, Murphy RL, Martin JM (2001) Grain fill duration in twelve hard red spring wheat crosses: genetic variation and association with other agronomic traits. Crop Sci. 41:1390-1395.

Tefera H, Belay G, Assefa K (2008) Genetic variation in $\mathrm{F}_{2}$ populations and their potential in the improvement of grain yield in tef (Eragrostis tef). Euphytica 164:105-111.

Tewolde H, Fernandez CJ, Erickson CA (2006) Wheat cultivars adapted to post-heading high temperature stress. J. Agron. Crop Sci. 192:111-120.

Tiwari VK, Rawat N, Chhuneja P, Neelam K, Aggarwal R, Randhawa GS, Singh K (2009). Mapping of quantitative trait loci for grain iron and zinc concentration in diploid A genome wheat. J. Hered. 100(6): 771-776.

van Beem J, Mohler V, Lukman R, van Ginkel M, William M, Crossa J, Worland AJ (2005) Analysis of genetic factors influencing the developmental rate of globally important CIMMYT wheat cultivars. Crop Sci. 45:2113-2119 doi:102135/cropsci20040665.

Van De Wouw, M., Van Hintum, T., Kik, C., Van Treuren, R. and Visser, B. 2010. Genetic diversity trends in twentieth century crop cultivars: a meta-analysis. Theor. Appl. Genet. 120:1241-52.

Varshney RK, Prasad M, Roy JK, Röder MS, Balyan HS, Gupta PK (2001) Intregated physical maps of 2DL 6BS and $7 D L$ carrying loci for grain protein content and pre-harvest sprouting tolerance in bread wheat. Cereal Res. Commun. 29:33-40.

Verma MM, Gill KS, Virk DS (1987) Genotype environment interaction its measurement and significance in plant breeding. Communication Centre, Punjab Agricultural University, Ludhiana, India.

Warburton ML, Crossa J, Franco J, Kazi M, Trethowan R, Rajaram S, Pfeiffer W, Zhang P, Dreisigacker S, Ginkel MV (2006) Bringing wild relatives back to the family: Recovering genetic diversity in CIMMYT improved wheat germplasm. Euphytica 149:289-301.

Weller JL and Ortega R (2015) Genetic control of flowering time in legumes. Front. Plant Sci. 6:207. 
Williams K, Taylor S, Bogacki P, Pallotta M, Bariana H, Wallwork H (2002) Mapping of the root lesion nematode (Pratylenchus neglectus) resistance gene RInn1 in wheat. Theor. Appl. Genet. 104:874-879.

Ya N, Raveendar S, Bayarsukh N, Ya M, Lee JR, Lee KJ, Lee GA (2017) Genetic diversity and population structure of mongolian wheat based on SSR markers: Implications for conservation and management. Plant Breed. Biotechnol. 5:213-220.

Yu J, Holland JB, McMullen MD, Buckler ES (2008) Genetic design and statistical power of nested association mapping in maize. Genetics 178:539-551.

Zanke C, Ling J, Plieske J, Kollers S, Ebmeyer E, Korzun V, Argillier O, Stiewe G, Hinze M, Beier S, Gana MW, Röder MS (2014) Genetic architecture of main effect QTL for heading date in European winter wheat. Plant Sci. 5:1.

Zhang D, Bai G, Zhu C, Yu J, Carver BF (2010) Genetic diversity population structure and linkage disequilibrium in US elite winter wheat. The Plant Genome 3:117-127.

Zhang L, Liu D, Guo X, Yang W, Sun J et al (2011) Investigation of genetic diversity and population structure of common wheat cultivars in northern China using DArT markers. BMC Genetics 12:42.

Zhang P, Dreisigacker S, Buerkert A, Alkhanjari S, Melchinger AE , Warburton ML (2006) Genetic diversity and relationships of wheat landraces from Oman investigated with SSR markers. Genet. Resour. Crop. Evol. 53:13511360.

Zikhali M, Griffiths S (2015) The effect of Earliness per se (Eps) genes on flowering time in bread wheat In Advances in Wheat Genetics: From Genome to Field Proceedings of the $12^{\text {th }}$ International Wheat Genetics Symposium pp 339345.

\section{Tables}




\begin{tabular}{|c|c|c|c|c|c|c|c|c|c|}
\hline Character & Min. & Max. & Range & Mode & Mean & CoV* & Variance & $\begin{array}{l}\text { Std. } \\
\text { Error* }\end{array}$ & $\begin{array}{l}\text { Std. } \\
\text { Dev* }\end{array}$ \\
\hline Days to flowering & 164.00 & 215.00 & 56.00 & 135.00 & 176.40 & 5.20 & 85.30 & 0.70 & 9.20 \\
\hline Days to maturity & 215.00 & 266.00 & 51.00 & 230.00 & 232.40 & 4.47 & 107.90 & 0.78 & 10.30 \\
\hline Number of tillers & 8.00 & 24.00 & 16.00 & 20.00 & 15.10 & 25.20 & 14.50 & 0.29 & 3.80 \\
\hline $\begin{array}{ll}\text { Plant height } \quad(\mathrm{cm}) \\
\end{array}$ & 67.50 & 115.00 & 47.50 & 90.00 & 92.80 & 10.20 & 90.20 & 0.72 & 9.50 \\
\hline Spike length $(\mathrm{cm})$ & 7.00 & 16.00 & 9.00 & 10.00 & 10.80 & 16.00 & 3.00 & 0.13 & 1.70 \\
\hline Spikelets spike $^{-1}$ & 15.00 & 24.00 & 9.00 & 19.00 & 19.80 & 8.60 & 2.90 & 0.13 & 1.70 \\
\hline Seed set spike ${ }^{-1}$ & 25.00 & 80.00 & 55.00 & 50.00 & 54.80 & 21.40 & 138.50 & 0.89 & 11.70 \\
\hline Seed length (cm) & 0.58 & 0.83 & 0.25 & 0.70 & 0.60 & 5.80 & 0.00 & 0.00 & 0.04 \\
\hline Seed breadth $(\mathrm{cm})$ & 0.29 & 0.42 & 0.13 & 0.35 & 0.30 & 6.50 & 0.00 & 0.00 & 0.02 \\
\hline $\begin{array}{l}\text { Thousand grain weight } \\
\text { (g) }\end{array}$ & 36.00 & 65.00 & 29.00 & 55.00 & 50.80 & 11.90 & 36.60 & 0.46 & 6.00 \\
\hline $\begin{array}{l}\text { Grain yield } \\
\left(\mathrm{Kg} \mathrm{ha}^{-1}\right)\end{array}$ & 2200.00 & 4200.00 & 2000.00 & 2800.00 & 3064.90 & 15.60 & 229182.80 & 36.00 & 478.70 \\
\hline
\end{tabular}

\begin{tabular}{|l|l|l|l|l|l|l|l|l|l|l|l|l|l|}
\hline able 2 & \multicolumn{7}{|c|}{ The analysis of variance (ANOVA) for 11 early maturity and related traits in wheat } \\
$\begin{array}{l}\text { ource of } \\
\text { ariation }\end{array}$ & df & DTF & NT & $\begin{array}{l}\text { PH } \\
(\mathrm{cm})\end{array}$ & $\begin{array}{l}\text { SL } \\
(\mathrm{cm})\end{array}$ & DTM & SSPS & NSPS & $\begin{array}{l}\text { GY } \\
\left(\mathrm{kg} \mathrm{ha}^{-1}\right)\end{array}$ & $\begin{array}{l}\text { TGW } \\
(\mathrm{g})\end{array}$ & $\begin{array}{l}\text { SL } \\
(\mathrm{cm})\end{array}$ & $\begin{array}{l}\text { SB } \\
(\mathrm{cm})\end{array}$ \\
\hline & & & & & & & & & & & & \\
\hline \\
\hline eplication & 1 & - & - & - & - & - & - & - & - & - & - & - \\
\hline ienotypes & 95 & $173.30^{*}$ & $26.80^{*}$ & $173.60^{*}$ & $5.06^{*}$ & $209.90^{*}$ & $293.10^{*}$ & $5.57 *$ & $456,928.10^{*}$ & $72.12^{*}$ & $0.003^{*}$ & $0.001^{*}$ \\
\hline rror & 95 & 2.7 & 1 & 6.4 & 0.34 & 7.1 & 13.9 & 0.95 & $3,802.70$ & 1.31 & 0 & 0 \\
\hline otal & 180 & - & - & - & - & - & - & - & - & - & - & - \\
\hline
\end{tabular}

Significant at 5\% level, DTF: days to flowering, NT: number of tillers, SL: spike length, DTM: days to maturity, SSPS: seed et per spike. NSPS: number of seeds per spike, GY: grain yield, TGW: thousand grain weight, SL: seed length, SB: seed readth 
able 3 Details of SSR markers used during the present study. The table also shows polymorphic information content (PIC value) of each marker

\begin{tabular}{|c|c|c|c|}
\hline Jcus & PIC Value & Locus & PIC Value \\
\hline gwm155A & 0.593 & Xgwm149C & 0.486 \\
\hline barc121A & 0.563 & $\overline{X g w m 190 A}$ & 0.713 \\
\hline barc121B & 0.490 & Xgwm249A & 0.492 \\
\hline barc124A & 0.498 & Xgwm271A & 0.606 \\
\hline barc124B & 0.496 & $\overline{X g w m 271 B}$ & 0.634 \\
\hline$\overline{c f a 2019 A}$ & 0.496 & $\overline{X g w m 271 C}$ & 0.588 \\
\hline$\overline{c f a 2019 B}$ & 0.569 & Xgwm271D & 0.492 \\
\hline cfa2049 & 0.614 & Xgwm30 & 0.528 \\
\hline cfa2141 & 0.536 & Xgwm337 & 0.587 \\
\hline$\overline{c f b 3266 A}$ & 0.232 & Xwmc1A & 0.589 \\
\hline$\overline{W m C 1 B}$ & 0.383 & Xgwm350B & 0.489 \\
\hline$\overline{c f b 3266 C}$ & 0.232 & Xgwm359A & 0.384 \\
\hline$\overline{c f d 267 B}$ & 0.838 & Xgwm383A & 0.296 \\
\hline$\overline{c f d 31 A}$ & 0.619 & Xgwm383B & 0.502 \\
\hline$\overline{c f d 31 B}$ & 0.709 & Xgwm383C & 0.667 \\
\hline$\overline{c f d 31 C}$ & 0.602 & Xgwm383D & 0.306 \\
\hline$\overline{c f d} 39 A$ & 0.196 & Xgwm610A & 0.648 \\
\hline$\overline{c f d 39 B}$ & 0.188 & $\overline{X g w m} 453 B$ & 0.774 \\
\hline$\overline{c f d 39 C}$ & 0.376 & Xgwm453C & 0.720 \\
\hline$\overline{g W m 11 A}$ & 0.660 & $\overline{X g w m 453 D}$ & 0.757 \\
\hline gwm11B & 0.582 & Xgwm538A & 0.499 \\
\hline gWm120A & 0.697 & Xgwm538B & 0.496 \\
\hline gWm148A & 0.384 & Xgwm538C & 0.458 \\
\hline gWm148B & 0.333 & Xgwm642A & 0.293 \\
\hline gwm149B & 0.643 & Xgwm642B & 0.356 \\
\hline
\end{tabular}

Table $4 \quad$ Allelic diversity in two different sub-populations (early vs late populations) using 26 SSR markers Population

Na (Number of different alleles)

Na Freq. $>=5 \%$

Ne (Number of effective alleles)

I (Shannon's Information Index )

Number Private Alleles

He (Expected heterozygosity)

\begin{tabular}{|c|c|c|}
\hline Population 1 (Early) & Population 2 (Late) \\
\hline 3.00 & 2.81 \\
\hline 2.73 & 2.64 \\
\hline 0.16 & 2.06 \\
\hline 0.37 & 0.76 \\
\hline 0.46 & 0.18 \\
\hline
\end{tabular}


Table 5 Analysis of molecular variance (AMOVA) among and within sub-population

\begin{tabular}{l|c|c|c|c|c|} 
Source & $\mathrm{df*}$ & Sum of squares & Mean sum of squares & Estimated variance & Per cent (\%) \\
\hline Among Pops & 1 & 222.48 & 222.48 & 5.82 & 9.00 \\
\hline Within Pops & 55 & 3135.76 & 57.01 & 57.01 & 91.00 \\
\hline Total & 56 & 3358.24 & - & 62.83 & 100.00 \\
\hline *df: degrees of freedom
\end{tabular}

Table $6 \quad$ Single marker analysis (SMA) of random and trait specific SSR markers with early maturity trait

a. Random SSRs

\begin{tabular}{|c|c|c|c|}
\hline Marker & Chromosome & R (\%) & P value \\
\hline Xcfd31 & $4 \mathrm{~A}$ & 13.340 & 0.005640 \\
\hline Xcfd39 & $4 \mathrm{D}$ & 8.0314 & 0.032662 \\
\hline Xgwm148 & 2B & 18.574 & 0.003494 \\
\hline Xgwm190 & 5D & 10.062 & 0.016204 \\
\hline Xgwm538 & $4 \mathrm{~B}$ & 7.616 & 0.039507 \\
\hline \multicolumn{4}{|c|}{ b. Trait specific/genic SSRs } \\
\hline Marker & Chromosome & $\mathrm{R}(\%)$ & P value \\
\hline Xwmc1 & 3B & 21.361 & 0.000335 \\
\hline Xgwm271 & $5 \mathrm{D}$ & 10.942 & 0.011961 \\
\hline
\end{tabular}

\begin{tabular}{|l|c|c|c|c|c|c|c|}
\hline $\begin{array}{l}\text { Table } 7 \\
\text { traits derived for cross Andalou (winter wheat) } \times \text { WS-1614 (spring wheat) }\end{array}$ \\
\hline Traits & $\begin{array}{c}\text { Parent 1 } \\
\text { (Andalou) }\end{array}$ & $\begin{array}{c}\text { Parent } \\
2 \\
(\text { WS- } \\
1614)\end{array}$ & $\mathrm{F}_{1}$ & $\begin{array}{c}\text { Min. } \\
\left(\mathrm{F}_{2}\right)\end{array}$ & $\begin{array}{c}\text { Max. } \\
\left(\mathrm{F}_{2}\right)\end{array}$ & $\begin{array}{c}\text { Mean } \\
\left(\mathrm{F}_{2}\right)\end{array}$ & $\begin{array}{c}\mathrm{STDEV}^{*} \\
\left(\mathrm{~F}_{2}\right)\end{array}$ \\
\hline Days to flowering & 181 & 158 & 165 & 150 & 185 & 164.3 & 6.4 \\
\hline Days to maturity & 260 & 230 & 240 & 225 & 260 & 239.6 & 9.3 \\
\hline Number of tillers & 20 & 22 & 21 & 10 & 26 & 17.8 & 3.2 \\
\hline Height (cm) & 80 & 81 & 98 & 62 & 114 & 85.8 & 12.4 \\
\hline Spike length (cm) & 10 & 12 & 15 & 9 & 14.5 & 12.5 & 1.4 \\
\hline $\begin{array}{l}\text { Number of spikelets } \\
\text { per spike }\end{array}$ & 19 & 20 & 24 & 17 & 123 & 24.7 & 16.8 \\
\hline Yield per plant (g) & 25 & 28 & 24 & 11 & 33.5 & 20.6 & 6.5 \\
\hline *STDEV : Standard deviation & \multicolumn{7}{|l|}{} \\
\hline
\end{tabular}




\begin{tabular}{|l|c|c|c|c|c|c|c|}
\hline Table 8 & \multicolumn{7}{|c|}{$\begin{array}{c}\text { Trait performance of } \mathrm{F}_{2} \text { mapping populations for early maturity and related traits } \\
\text { derived } \\
\text { for cross CIMMYT-4060 (spring wheat) }\end{array}$} \\
\hline Trait & $\begin{array}{c}\text { Parent 1 } \\
\text { (CIMMYT-4060) }\end{array}$ & $\begin{array}{c}\text { Parent 2 } \\
\text { (Aardvark) }\end{array}$ & $\mathrm{F}_{1}$ & $\begin{array}{c}\text { Min. } \\
\left(\mathrm{F}_{2}\right)\end{array}$ & $\begin{array}{c}\text { Max. } \\
\left(\mathrm{F}_{2}\right)\end{array}$ & $\begin{array}{c}\text { Mean } \\
\left(\mathrm{F}_{2}\right)\end{array}$ & $\begin{array}{c}\text { STDEV } \\
\left(\mathrm{F}_{2}\right)\end{array}$ \\
\hline Days to flowering & 171 & 198 & 178 & 160 & 198 & 177.1 & 11.4 \\
\hline Days to maturity & 225 & 275 & 230 & 218 & 276 & 249.7 & 19.4 \\
\hline Number of tillers & 12 & 24 & 18 & 10 & 26 & 18 & 3.7 \\
\hline Height (cm) & 103 & 67.5 & 90 & 36 & 111 & 74.4 & 18.3 \\
\hline Spike length (cm) & 12 & 16 & 14 & 8 & 14 & 11.3 & 1.5 \\
\hline $\begin{array}{l}\text { Number of spikelets } \\
\text { per spike }\end{array}$ & 18 & 20 & 20 & 10 & 30 & 21 & 4.7 \\
\hline Yield per plant (g) & 18 & 24 & 25 & 12 & 33.5 & 21.6 & 6.4 \\
\hline *STDEV : Standard deviation & \multicolumn{7}{|l|}{} \\
\hline
\end{tabular}

\section{Figures}
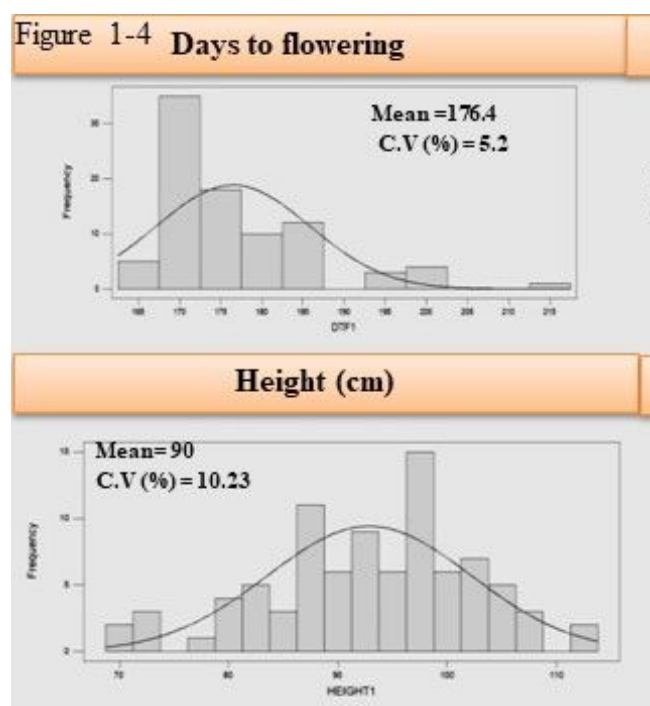

Seed set per spike

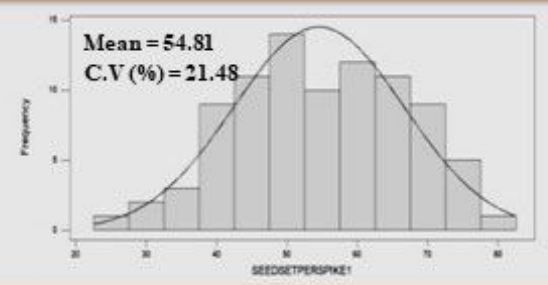

Seed length (cm)

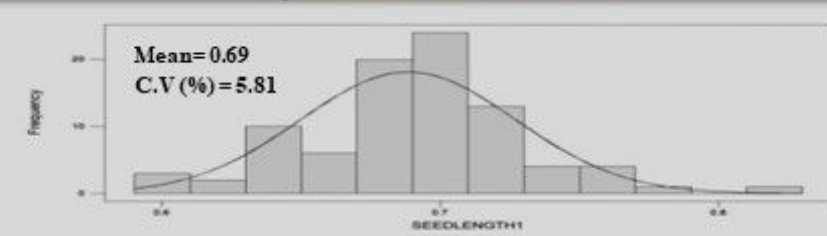

Days to maturity

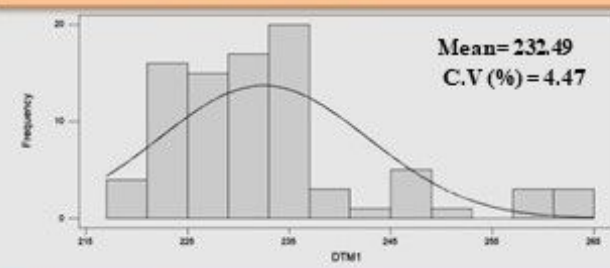

Spike length (cm)

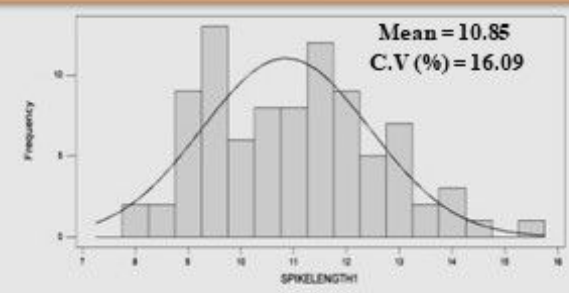

1000 grain weight (g)

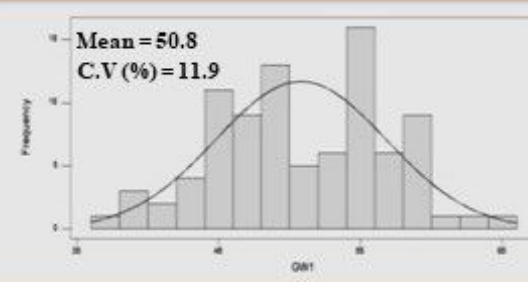

$\infty$

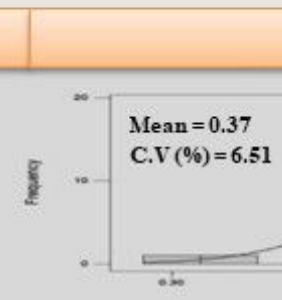

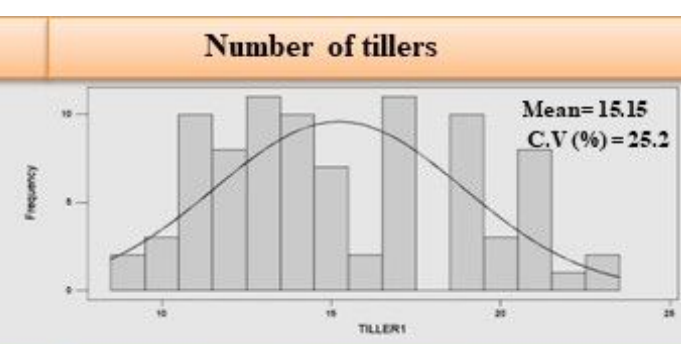

Spikelets per spike

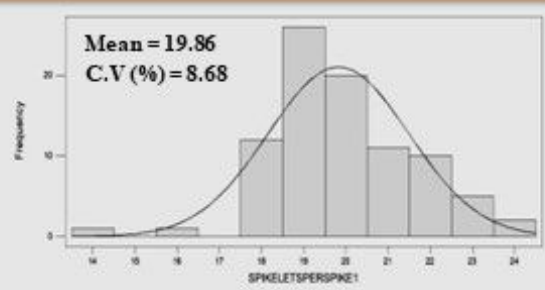

Grain yield (kg/ha)

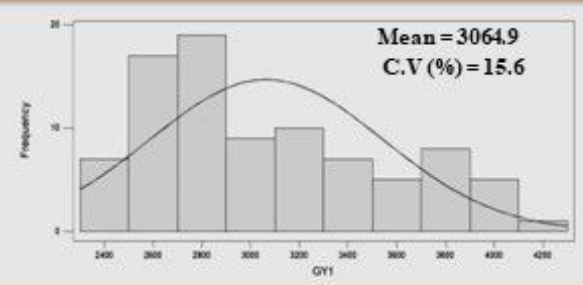

Seed breadth (cm)

Fig. 1 Frequency distribution for 11 quantitative traits recorded during the present study on 96 wheat genotypes 
Frequency distribution for 11 quantitative traits recorded during the present study on 96 wheat genotypes
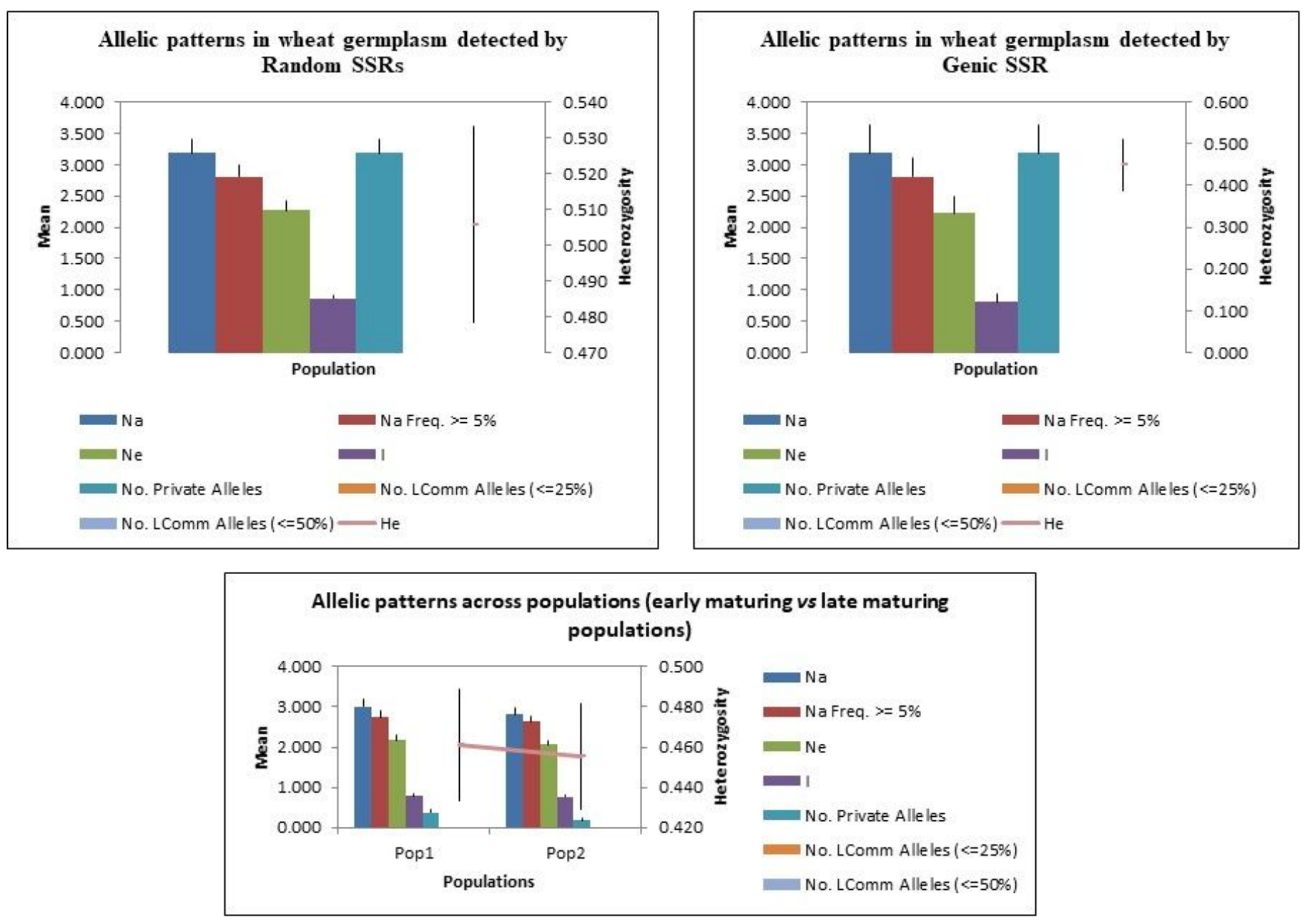

Fig. 2 Allelic diversity across different populations. The figure shows comparison of allelic diversity in different sub-populations and by different type of SSR markers (genic vs random SSR markers) (Pop1: Early maturing; Pop2: Late maturing)

\section{Figure 2}

Allelic diversity across different populations. The figure shows comparison of allelic diversity in different subpopulations and by different type of SSR markers (genic vs random SSR markers) (Pop1: Early maturing; Pop2: Late maturing) 

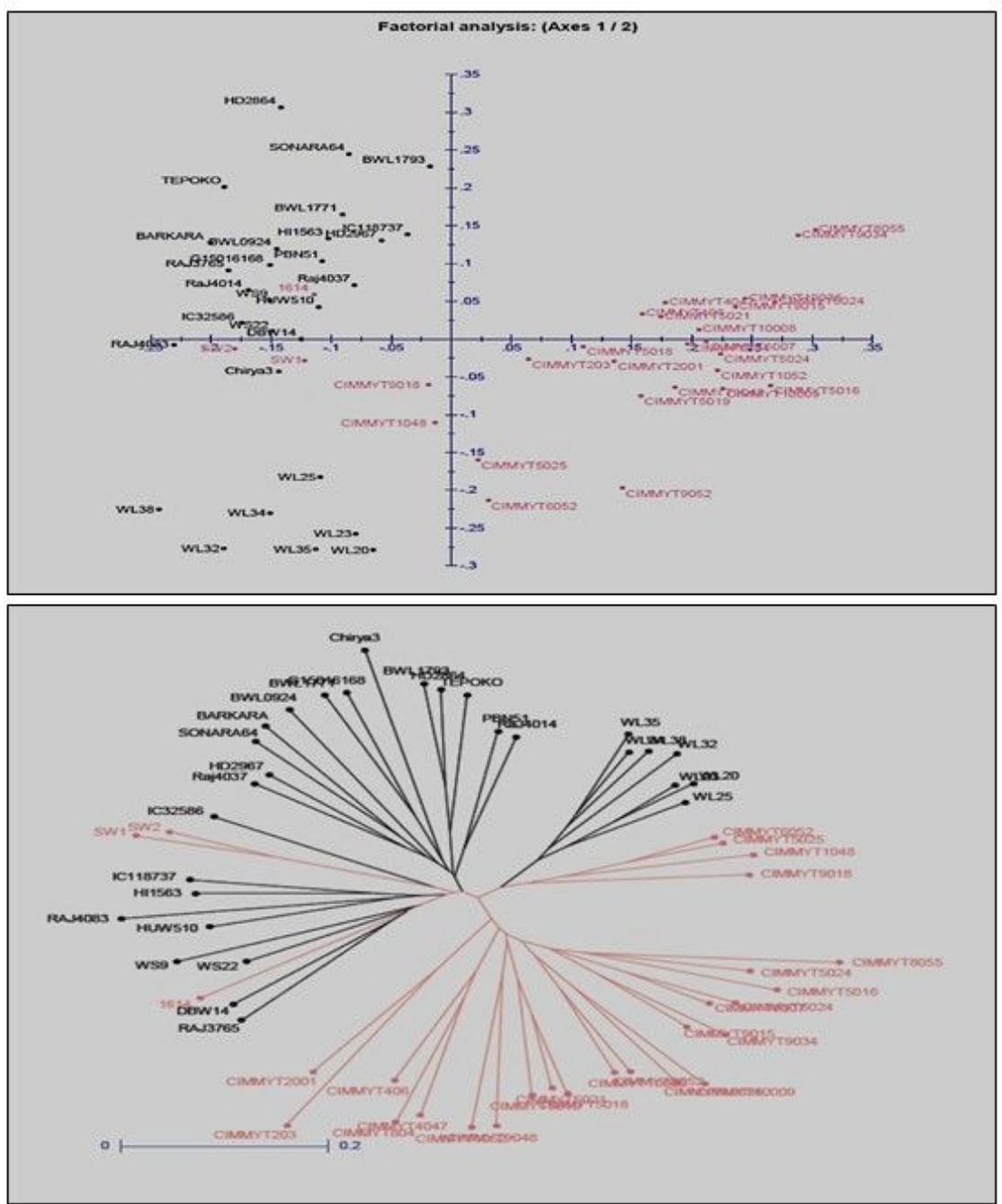

Fig. 3 PCoA and Nei's genetic distance based dendrogram using random SSR markers. Genotypes highlighted with red color are early maturing genotypes while as genotypes highlighted with black colour are late maturing genotypes

\section{Figure 3}

PCoA and Nei's genetic distance based dendrogram using random SSR markers. Genotypes highlighted with red color are early maturing genotypes while as genotypes highlighted with black colour are late maturing genotypes 

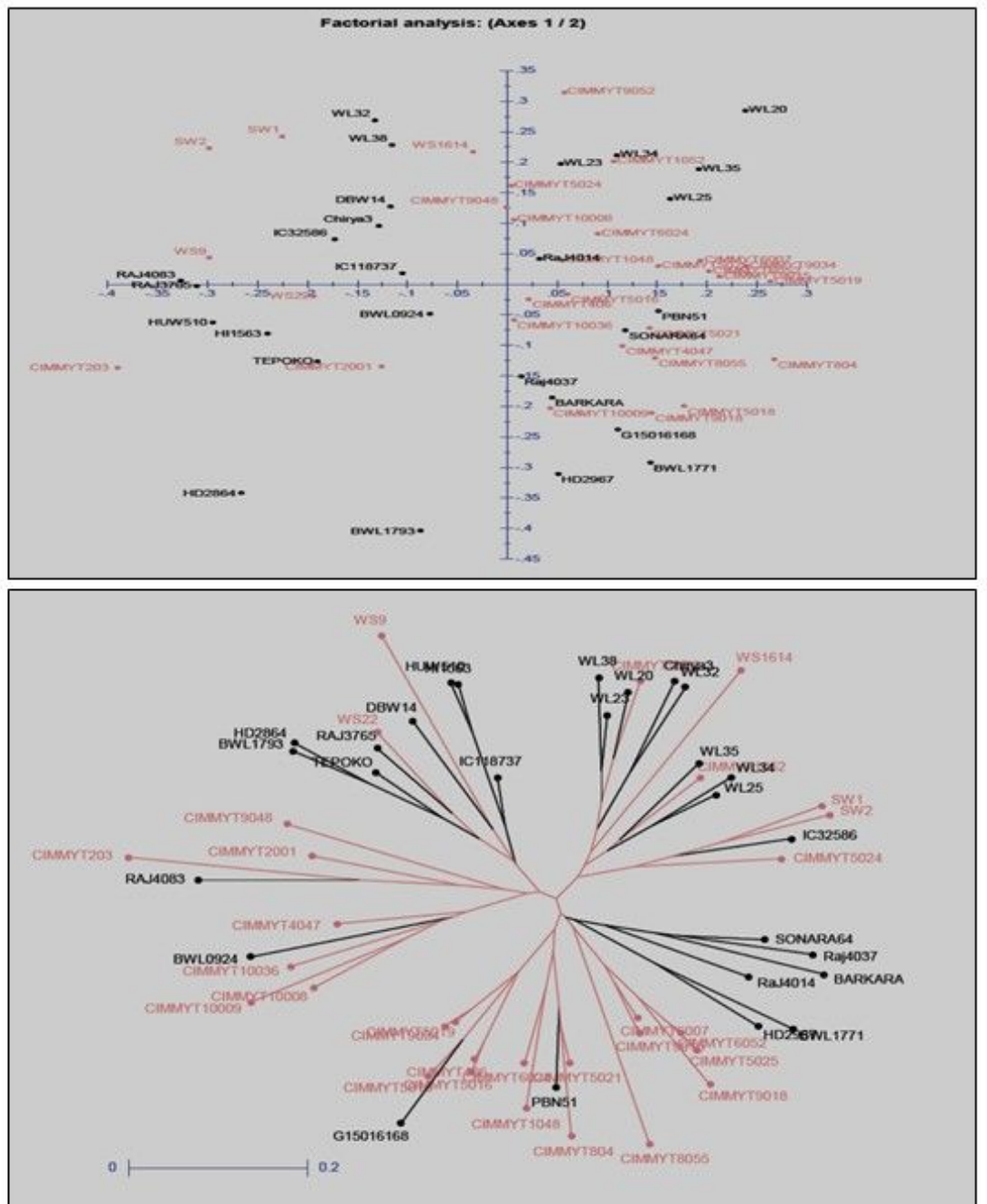

Fig. 4 PCoA and Nei's genetic distance based dendrogram generated using trait specific/genic SSR markers. Genotypes highlighted with red color are early maturing genotypes, while as genotypes with black colour are late maturing genotypes

\section{Figure 4}

PCoA and Nei's genetic distance based dendrogram generated using trait specific/genic SSR markers. Genotypes highlighted with red color are early maturing genotypes, while as genotypes with black colour are late maturing genotypes 